\title{
Need Analysis of English for Pharmacy Students at Medical Vocational High School of Prof. Dr. Moestopo
}

\author{
Wawat Srinawati ${ }^{1}$ \\ \{wawatsrinawati@gmail.com ${ }^{1}$ \} \\ ${ }^{1}$ English Education Departmenet, School of Teaching, Training and Education, STKIP \\ Muhammadiyah Bogor, Jl. Raya Leuwiliang No. 106 Bogor, Jawa Barat 16640, Indonesia.
}

\begin{abstract}
The aims of this study were to investigate and analyse the needs of students in learning English Medical Vocational High School (SMK Kesehatan) of Prof.Dr. Moestopo. The increasing number of vocational schools has contributed to the rapid expansion of English for Specific Purpose (ESP) in Indonesia. The first stage in developing learning materials for ESP conducting needs analysis. It refers to activities in collecting information as the basis for academic development of a particular group of students. The data were collected through questionnaires and interview. The result showed that : 1) Students need materials that meets their needs, particularly in general and medical vocabulary since most of them have difficulties to understand the meaning of words, 2) Students need more practices in speaking compared to other language skills, 3) Students tend to learn English because of their needs to improve language competences than to prepare their professional job in the future, 4) The teacher method that suit to the students were based on the materials itself. It can be teachers or students centred learning. This study recommended that students need more extra times to learn English. Besides, teacher should create supportive learning environment to motivate them in study English.
\end{abstract}

Keywords: English for Specific Purpose, Need analysis, Vocational high school

\section{Introduction}

Language is used as a tool to express someone's thought an ideas (Ramelan, 1984). Language devided into two forms, spoken and written for the spoken one, in our daily life, people use lanuguage to communicate each other as commuincation is one of the ways to interact with others. Speaking is an output skill which is integrated to other skills such as listening nad reading. It becomes one of the most important skills taht is used by people in daily activities. People would rather to speak to give their comments, suggesttions, advises, ideas, commands, and any others by speaking than they write them down. Many domain and of life and society has been influenced by the English as an international language (Hossain, 2013). It becomes the dominant language as the medium of communication in specific fields, for example : trade, diplomacy, pharmacy, tourism, maritime, technology, etc. Censequency, the developing interest of English has added to the quick extension in English for Specific Purpose (ESP) since 1960 (Otilia, 2015). ESP is a way to deal with language teaching in which all decisions as to substance and strategy depand on the purpose of students in learning ( Hutchinson and Waters, 1987). It deals with preparing students to be ready to use English in academic, professional or workplace setting. It is all completely different with General English (GE) that focus in provide students's knowledge and practice to be able to speak English for geneal aims. ESP theoritical framework includes its various stages in terms of 
need analysis, syllabus desain, materials productions, methodology, implemention, and evaluation (Qattous, 1995).

In fact, most English teachers of vocational high school in Indonesian only teach General English (GE) to their students. To this reason, the writer interested to analyze the English needs of students in pharmacy major at vocational high school of pharmacy SMK Kesehatan Prof. Dr. Moestopo. Moreover, the research questions of this study are as follows: 1). What the needs of pharmacy students, particulary in language skills. 2) what are the students' perspective of English in relation to their professional needs, 3) what is the most appropriate teaching method for students.

\section{Need Analysis of English for Parmacy Students}

English for specific purposes is necessity of English linguistic by certain group which originally from non-English existence to bear out their particular object study. This approach was growing as not as the pure education discipline. 6 The ESP purpose is to develop English proficiency which faces condition or circumstance to use it (Afzali\&Fakharzadeh: 2009). Then, ESP is equipment which supports the speaker (User) based on the specialization. The role of needs analysis in any ESP course is invaluable. It is considered as a prerequisite in any course design (Richterich and Chancerel, 1987). "It is also considered as one of the key stages in ESP, the others being the syllabus design, selection and production of materials, teaching and learning, and evaluation." (Evans,and St John, 1998). Johns (1991, cited in Li, 2014) also regards needs analysis as the first step in curriculum design for it can provide validity and relevancy for all the follow-up curriculum design activities.

Brown (2001) states that need analysis refers to the activities involved in gathering information that will serve as the basis for developing a curriculum that will meet the learning needs of a particular group of learners.Nunan (1994) argues that "needs analysis is a set of procedures for specifying the parameters of a course of study. Such parameters include the criteria and rationale for grouping learners, the selection and sequencing of course content, methodology, course length, and intensity and duration." Reading and writing are activities that related to the English learning on ESP for the students of pharmacy. Most of the students choosing topic which is related to the program as the activity required to be put on the syllabus

\section{Method}

This study was conducted at SMK Kesehatan Prof Dr. Moestopo, This study used qualitative and quantitative method to answer the research questions. The research instruments of this study is a set of questionnaires which is arranged in multi-option question pattern. This questionnaire was distributed to 50 students from two classes in the third grade of SMK Kesehatan Prof. Dr. Moestopo. The first and second grade were not chosen to participant in this study because they were still in the beginning of their study, and they could not give clearly idea on their needs toward English learning (Alastal \& Shib as cited in Ibrahim, 2016). In addition, an English teacher were also invited to participate in this study through semistructured interview.

\section{Students perceptive of English in Relation to their professional needs}

The aims of this question was to know the students perception of their English ability from the table above, it is obvious that just over half of students in this study stated that their English language ability were good $56 \%$. In contrary, $38 \%$ of the of the students rated 
themselves as poor in the language ability. Besides, there were $5 \%$ of the students who viewed that their English were very good, and for about 3\% of the students considered that their English very poor. Actually, the number of students who thought they have good and poor ability in English were fairly balanced.

1. How is your language ability?

2. What do you think about your English development during your study at your school?

3. Why are you learning English ?

Table 1. Result of Question 1

\begin{tabular}{cc}
\hline Very good & 5 \\
Good & 56 \\
Poor & 38 \\
Very Poor & 3 \\
\hline
\end{tabular}

There were $53 \%$ of students htought that their level of English were increased during studying at school. Further, 13\% of students were not sure whether their English level increase or not. Beside, $3 \%$ of students stated that they level of English were not increased.

Table 2. Result Question 2

\begin{tabular}{ll}
\hline My English level is increased & 53 \\
My English level is not increased & 34 \\
Not sure if it increases or not & 13 \\
\hline
\end{tabular}

The table above shows that to improve language skill ability as their main reason to learn English $67 \%$. Meanwhile, $15 \%$ of the students thought that their reason to study English because it was a compulsory subject. None chose to go abroad and to interact with other as their reason to learn English. In addition, there were $2 \%$ of the students who viewed that all given answerd were the correct answers. It seems that most of students were aware about the importance to study English. As stated by Hutchinson and Water (1987) that most of language learners are mindful of the purpose for which they learn the language.

Table 3. Result Question 3

\begin{tabular}{lc}
\hline Improve language skills ability & 67 \\
Compulsory subject in school & 15 \\
Widen job opportunities & 12 \\
Prepare for studying in University & 6 \\
Interact with other & 0 \\
Go abroad & 0 \\
Others & 2 \\
\hline
\end{tabular}

\subsection{The needs of students in English language school}

4. What kinds of English language skill do you need to improve?

5. What skills are most often taught in class by your English teacher? 
Table 4. Result of Question 4

\begin{tabular}{lc}
\hline Listening & 10 \\
Reading & 14 \\
Speaking & 70 \\
Writing & 6 \\
\hline
\end{tabular}

It was found that students need to improve speaking skill $70 \%$. For about $10 \%$ and $14 \%$ of the students stated that listening and reading become the skill which they need to improve. There were only $6 \%$ of the total number students who choose writing as the skill they need to improve. Robinson is cited in Boroujeni (2013) explained by oral proficiency is the best indication of language mastery. This seems a reason for many students to choose speaking as their most wanted skills to improve.

Table 5. Result Question 5

\begin{tabular}{lc} 
& Table 5. Result Question 5 \\
\hline Speaking & 52 \\
Reading & 26 \\
Listening & 10 \\
Writing & 12 \\
\hline
\end{tabular}

The most often taught skills in the class by teacher was speaking $52 \%$. Reading $26 \%$ in the second place as the most often taught skill in the English class. Furthermore, there were $12 \%$ of the students who choose writing and $10 \%$ of the students who stated that listening was the most often taught materials by teacher in the class.

\subsection{The most needed learning materials}

1. Do you think that English materials at school has meet your needs to be a pharmacist?

2. How important is vocabulary practice for you in the class?

3. How important is grammar practice for you in the class?

Table 6. Result Question 6

\begin{tabular}{lc}
\hline Yes & 38 \\
No & 9 \\
Sufficient & 53 \\
\hline
\end{tabular}

According to the table above, $53 \%$ of the students stated that English langauge teaching materials was sufficient to meet their needs as a pharmacy. Meanwhile, $38 \%$ of students viewed that English language teaching materials had fulfilled their need. There were only $9 \%$ of students who thought that the materials had not fulfilled their needs as pharmacist candidate. Actually, based on the interview, the teacher used the General English book for vocational high school. It was particulary concern to English for pharmacy. It seems that the students have luck of knowladge regarding to ESP and their needs as pharmacist in the future.

Table 7. Result Question 7

\begin{tabular}{lc}
\hline Strongly important & 40 \\
Important & 60 \\
Not important & 0 \\
\hline
\end{tabular}




\begin{tabular}{ll}
\hline Strongly not important & 0 \\
\hline
\end{tabular}

It is obvious that students agreed to the important of vocabulary practice in the class. There were $60 \%$ of students who stated strongly important to have vocabulary practice and followed by $40 \%$, students who agreed that vocabulary practice were important. None of students who stated disagree to the statement taht vocabulary practice was not important.

Table 8. Result of Qustion 8

\begin{tabular}{lc}
\hline Strongly important & 28 \\
Important & 72 \\
Not important & 0 \\
Strongly not important & 0 \\
\hline
\end{tabular}

The perpose of the questions was to know the perceptive of students in grammar practice. A large number of students stated taht grammar practice were important $72 \%$ Besdides $28 \%$ of the students thought taht grammar practice were strongly important. No one of the students who viewed taht grammar practice was not or strongly not important.

\subsection{The appropriate teaching method for students}

4. How is your favourite English class?

5. What is you difficulty in studying English?

6. Is the time to study English at school enought to learn English ?

7. What are your suggestions for better learning of English at school?

Table 9. Result of Question 9

\begin{tabular}{lc}
\hline Class with teacher expalin more and & 54 \\
less activities for students & 12 \\
Class with working alone activities & 34 \\
Class with a lot of activity group & \\
work/pair
\end{tabular}

$54 \%$ of students prefered a class with more explanation from teacher and less activities for the. This result might have corralation with the first questions which asking students' ability in English. For about 34\% of students thought that they have poor ability in English so thay preffred to have less activities or teacher centered learning. Moreover, $34 \%$ of students' prefarred group of pair work compared to working alone activities. There were only $12 \%$ of the students who choose working alone pattern as their prefarance in the language teaching class.

Table 10. Result of Question 10

\begin{tabular}{ll}
\hline Difficult to say in English & 32 \\
Many vocabularies are not understand & 58 \\
Others & 10 \\
\hline
\end{tabular}

Just over $58 \%$ of students thought that they have difficulties to understand vocabularies. Besides, $32 \%$ of students face difficulties to speak in English. Others difficulties thought by students were : 1. Could not understand what the teacher explain, 2. Typo and writing. In can be inffered thta students need more vocbuary practice in language teaching. 
Table 11. Result of Question 11

\begin{tabular}{lc}
\hline Yes & 25 \\
No & 54 \\
Others & 21 \\
\hline
\end{tabular}

Shows that $54 \%$ of the students viewed that the duration in studying English at school was not enought. For about $25 \%$ students stated taht the time allocation to study English was enought. Further, $21 \%$ of students thought that they need to learn English more, for example : every day, three hours a day, twice in week, tree times in a week, or four times in a week. The more study time and practice to study English, will certainly be balanced with students I' ability in English language.

Table 12. Result of Question 12

\begin{tabular}{lc}
\hline The improvment of teaching method & 69 \\
Learning materal meet the students' need & 25 \\
Others & 6 \\
\hline
\end{tabular}

A major of students, which is about $69 \%$ of students suggest the method of teaching learning of English should be improved. This improvement in teaching method will motivate students to study English so that the goals of learning English can be achieved. Aside from that, approximately $25 \%$ of students thought that the learning materialsshould be in lined with students need for the future career. Some students ....suggest the teacher and students to use English during the class and institution provided such an English club as extracurricular activities for students.

\section{Need Analysis of English at Medical Vocational High School}

The aim of this study is improving the student's analysis of English. To achieve this goal, this study must solve a number of arising problems which come from the teaching method, the teacher or the students themselves. The teacher as a facilitator in the classroom has to facilitate and teach students to achieve the learning objectives. In Analysis, the appropriate technique can help a lot to get the learning objectives. Need analysis of English for parmacy students assumed as one of the effective technique to be applied in learning process. The writer designs as the illustration of this study. 


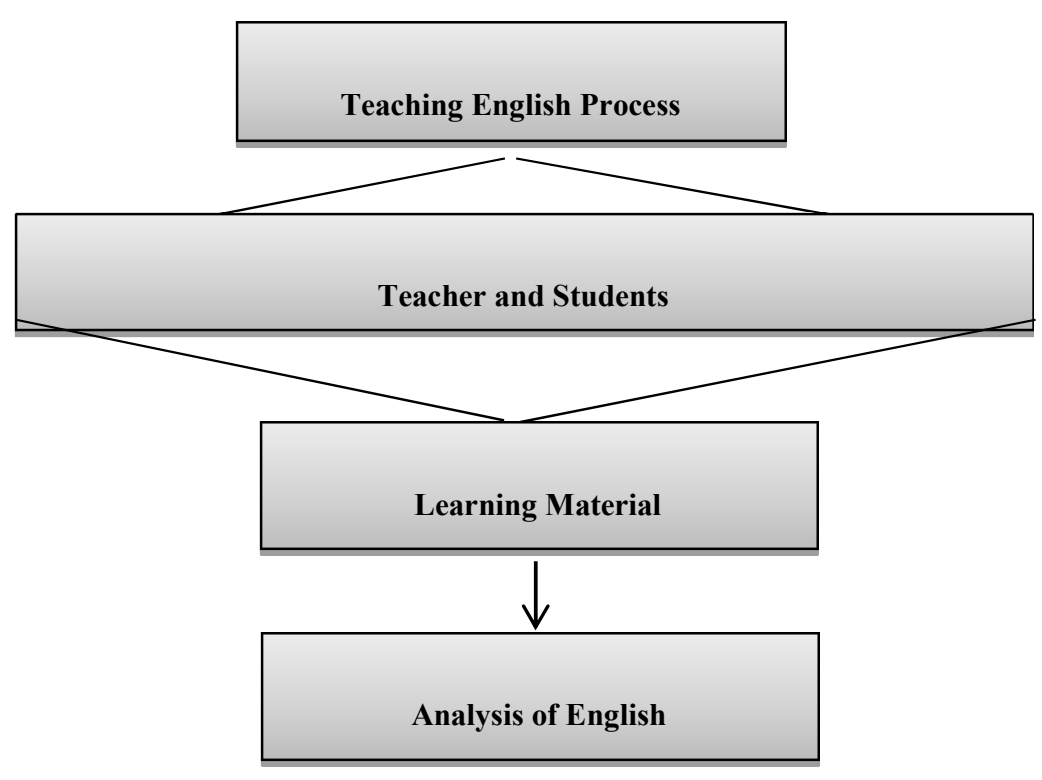

Fig. 1. The Schema of Conceptual

\section{Conclusion}

To conclude, most students learn English because they want to improve their language skills compared to their professional needs in the future. Further, students need more practice in speaking since most of them face difficulties to speak in English. Students need more materials which meet their needs as pharmacist candidate and understand and they need more general vocabulary building in classroom due to their difficulties in understanding words. They also need to learn pharmacy term in English. Moreover, the teaching method were dicided by teachers based on the material itself. It can be students centred or teacher centred learning.

\section{References}

[1]. Afzali, Kand MehrnooshF.. 2009. A needs analysis survey:The case of tourism letter writing in Iran. Iran. Sheikhbahaee University. (www.espworld.info/Articles_22/PDF/A\%20n eeds\%20analysis\%20survey.pdf)

[2]. Al-Hamlan, S. Abdulaziz Baniabdelrahman, A Ahmad (2015). Needs Analysis Approach to EFL Syllabus Development for Second Grade Students in Secondary Education in Saudi Arabia : A Descriptive Analytical Approach to Students' Needs. American International Journal of Contemporary Research, 5. (1).

[3]. Brown, Jean D.1996. The Elements of Language Curriculum; A Systematic Approach to Program Development. Boston, Mass.: Heinle\&Heinle Publishers.

[4]. Boroujeni, Samira A., \& Fard, Fateme, M.(2013) A Needs Analysis of English for Specific Purposes (ESP) Course for Adoption of Communicative Language Teaching: A Case of Iranian First Year Students of Educational Administrastion. International Journal of Humanities and Social Science Invention. 2 (6) , 35-44 retrived from: http:/ijhssi.org/papers/v2(6)version3/h0263035044pdf 
[5]. Evan, Tony Dudley. and Maggie St Johns. 1998.Developments in ESP a MultiDisciplinary Approach Cambridge: Cambridge University Press.

[6]. Hossain MD Jamal (2013) ESP Needs Analysis for Engineering Students: A Learner Centered Approach. Journal of Presidency University, 2 (2)

[7]. Hutchinson, Tom \& Alan Waters. (1987) English for Specific Purposes. Cambridge : Cambridge UP

[8]. Ibrahim, buelgasim, SEM. (2006) ESP Needs Analysis : A Case Study of PEH Students, University of Khartom. Sino_US English teaching, 13 (12)

[9]. Otila Simion Minodora ( $20 \overline{15}$ ) Needs Analysis in Eglish for Specific Purposes. Economy Series $2(1)$

[10]. Nunan,David. 1988. Syllabus Design. Oxford. Oxford University Press

[11]. Qattous, Kathem Mohammed (1995) The Cultural Dimention of English for Specific Purposes (Doctoral Theses, Durham University, United Kingdom). Retrieved from: http: //etheses.dur.ac.uk/5478 http://www.aijcrnet.com/journal/Vol_5_nO_1february_2015/15.pdf 